\title{
Viability of bull semen extended with commercial semen extender and two culture media stored at $24^{\circ} \mathrm{C}$
}

\author{
A.M. Raseona ${ }^{1 \#}$, O.A. Ajao ${ }^{1}$, L.D Nethengwe', L.R Madzhie ${ }^{1}$, T.L. Nedambale ${ }^{2}$ \& D.M. Barry ${ }^{1}$ \\ ${ }^{1}$ Centre of Excellence in Animal Assisted Reproduction, School of Agriculture, University \\ of Venda, Private Bag X5050, Thohoyandou, 0950, South Africa \\ ${ }^{2}$ Tshwane University of Technology, Department of Animal Science, Private Bag X680, Pretoria, 0001, South Africa
}

(Received 29 August 2016; Accepted 13 December 2016; First published online 17 December 2016)

Copyright resides with the authors in terms of the Creative Commons Attribution 4.0 South African License.
See: http://creativecommons.org/licenses/by/4.0/za
Condition of use: The user may copy, distribute, transmit and adapt the work, but must recognize the authors and the South African
Journal of Animal Science.

\begin{abstract}
The aim of this study was to evaluate the viability of bull spermatozoa diluted with commercial semen extender and two culture media stored at controlled room temperature $\left(24^{\circ} \mathrm{C}\right)$ for 72 hours. Two Nguni bulls were used for semen collection with the aid of an electro-ejaculator. After macroscopic evaluation, semen was pooled and aliquoted randomly into Triladyl, modified Ham's F10, and TCM-199 culture media, and then stored at $24{ }^{\circ} \mathrm{C}$. Sperm motility parameters, morphology, and viability were analysed with computer aided sperm analysis (CASA) after 0, 24, 48 and 72 hours. The study was replicated four times, and data were analysed using analysis of variance (ANOVA). Triladyl had significantly higher sperm viability rate (41.3\%) and total motility rate (96.3\%) for 72 hours than modified Ham's F10 (86.8\%; 26.5\%) and TCM-199 $(76.7 \%$; $25.0 \%)$ culture media. Ham's F10 had higher progressive motility rate $(37.8 \%)$ than the other extenders TCM-199 (31.7\%) and Triladyl (23.4\%). There was no significant difference in viability rate between Ham's F10 (26.5\%) and TCM-199 (25.0\%) after 72 hours' storage at $24{ }^{\circ} \mathrm{C}$. Furthermore, no significant difference was observed in total sperm abnormalities, except for reacted acrosomes and absent tails, between the two Nguni bulls. Nguni semen can be preserved in Triladyl or modified Ham's F10 and TCM-199 culture media, stored at $24^{\circ} \mathrm{C}$, and stay viable for 72 hours.
\end{abstract}

Keywords: Ham's F10, TCM-199, Triladyl, sperm motility, viability

\#Corresponding author: andrearaseona@gmail.com

\section{Introduction}

Provision of improved livestock genes into rural livestock production systems can play an important role in changing poor livestock farming conditions in rural areas that focus on household subsistence (Lebbie \& Kagwini, 1996), into viable commercial enterprises that are open to the global market. Livestock and crop farming are the major forms of agriculture in the province of Limpopo in South Africa, with communal cattle farming enterprises comprising approximately $50 \%$ of farming in remote areas of Vhembe district. Production, however, is primarily for subsistence purposes with little marketable surplus (Stroebel et al., 2011; Mafukata, 2014; 2015). Furthermore, the livestock animals (cattle, goats and sheep) in the Vhembe district still show clear signs of past inbreeding, which results in low production. The indicators include small body size, slow average daily weight gain, decreased fertility, extended calving intervals, and loss of natural resistance against diseases and parasites. An artificial insemination programme could be the most appropriate reproductive technology to improve the genetic material of the livestock animals in the community. However, implementation of such a programme is challenging because of limitations such as the availability of liquid nitrogen, storage of semen tanks, and the cost of semen tanks.

Successful preservation of semen in liquid state requires that sperm motility and metabolic activity reduction caused by refrigeration should be reversible (Yoshida, 2000). Cooled bull semen is used mainly in fixed-time artificial insemination programmes (Crespilho et al., 2014), because of its limited shelf life (Vishwanath \& Shannon, 2000; Verberckmoes et al., 2004). However, the advantage of using fresh semen includes the ability to inseminate a large number of animals in a short time (Bucher et al., 2009) with relatively low sperm numbers per insemination, high sire utilization, inexpensive storage, and ease of use in the field (Vishwanath \& Shannon, 2000; Verberckmoes et al., 2004). 
Preservation of bovine semen in fresh and frozen states has been studied substantially (Vishwanath \& Shannon, 2000). Egg and milk-based extenders are used extensively for semen extension and storage of animal species (Kasimanickam et al., 2011; Khan et al., 2012). In addition, vegetable origin extenders are in vogue, which are considered alternatives to milk or egg yolk-based extenders (Gil et al., 2003). According to Aires et al. (2003), soy lecithin-based extender is superior to egg yolk-based extender for bovine and ram semen. Singh et al. (2012) observed that $25 \%$ soya-based extender produced better motility, viability, and membrane and acrosome integrity of bovine semen at $5{ }^{\circ} \mathrm{C}$ at different time intervals. Also, Kasimanickam et al. (2011) reported that DNA fragmentation index, mitochondrial membrane potential, and semen motility were improved in particular in the soy-based extender compared with the milk-based extender during liquid storage.

Caprogen diluent has been used to preserve bull semen at room temperature. Originally, Caprogen diluent was developed for preservation of bull semen at $5{ }^{\circ} \mathrm{C}$, but because of good fertility results obtained after being stored at $15-27^{\circ} \mathrm{C}$, it was then used mostly at ambient temperature (Shannon \& Curson, 1984). An alternative to Caprogen diluent, CEP-2 diluent, has been proved to be the first medium that can be used as a diluent for prolonged preservation of fresh bovine semen (Verberckmoes et al., 2005) at room temperature.

Culture media for embryo growth were first described in 1912 for the growth of an embryo of a rabbit. These culture media, like Earle's, Ham's F-10, Tyrode's T-6, and Whitten's WM1, were based on various salts and were constructed to support the development of somatic cells and cell lines in culture. The use of TCM-199, supplemented with $10 \%$ foetal bovine serum, pyruvate, follicle-stimulating hormone, estradiol, and antibiotics, remains the method used in most laboratories to culture mature bovine embryos (Sirard et al., 1988). Frozen-thawed bull semen diluted in TCM-199 supplemented with antioxidants did not show significant improvement in sperm motility characteristics (Bucak et al., 2010; Sarı̈zkan et al., 2014), but increased post-thaw sperm acrosome damage and abnormalities (Sarıözkan et al., 2014). To the knowledge of the authors, there is no study available, to date, on the liquid preservation of freshly collected bull semen using TCM-199 or Ham's F10 culture media. The objective of this study was therefore to evaluate the viability of bull spermatozoa preserved for 72 hours in modified Ham's F10 and TCM-199 culture media and the commercial extender Triladyl, stored at a controlled room temperature of $24^{\circ} \mathrm{C}$ as an alternative to frozen/thawed semen straws.

\section{Materials and Methods}

The study was conducted at the Centre of Excellence in Animal Assisted Reproduction of the University of Venda, Thohoyandou. Two Nguni bulls of good body condition score and proven fertility records, kept under intensive care, at the ages of 2 to 3 years, were used for semen collection. The study was carried out in strict accordance with the recommendations in the Guide for the Care and Use of Animals under the guidelines of the University of Venda Animal Ethics Committee. Semen collection was done with an electro-ejaculator. Collected semen was transported to the laboratory within 10 minutes. Only uncontaminated semen samples with progressive motility (PM) of $>70 \%$, morphological defects of $<20 \%$, and concentration higher than $1.0 \times 10^{6}$ were pooled together to eliminate individual differences. Pooled semen was randomly aliquoted into two culture media, TCM-199 and Ham's F10; Both were supplemented with $0.025 \mathrm{~g} / 4 \mathrm{~mL}$ maltose monohydrate $\left(\mathrm{C}_{12} \mathrm{H}_{22} \mathrm{O}_{11} \cdot \mathrm{H}_{2} \mathrm{O}\right), 10 \%$ bovine serum albumin (BSA), $10 \%$ HEPES buffer, and $1 \%$ antibiotic cocktail (penicillin, streptomycin and fungizone), and in a commercial extender Triladyl. A dilution ratio of $1: 4$ (semen : extender) was used. Extended samples were stored at a controlled room temperature of $24^{\circ} \mathrm{C}$ for $72 \mathrm{~h}$.

The sperm motility parameters (total motility(TM), progressive and rapid motility (PRM), curvilinear velocity (VCL), average path velocity (VAP), linearity (LIN), straight line velocity (STR) and wobble (WOB)) were evaluated with the computer-aided sperm analysis (CASA) system (Sperm Class Analyzer ${ }^{\circledR}$ (SCA) 5.3, Microptic, Barcelona, Spain) at 0, 24, 48 and $72 \mathrm{~h}$. Five fields were captured for each analysis of the samples with a $10 x$ objective.

Abnormal spermatozoa, such as acrosome-reacted, coiled or bent tails, double heads or tails, and distal and proximal droplets, were determined by staining with Spermac $\AA$ (Stain Enterprises, P.O. Box 152, Wellington 7654, South Africa). Sperm smears for each bull were first prepared by pipetting a $15 \mu \mathrm{L}$ drop of a non-pooled extended semen sample on a clear end of slide, smeared across, and allowed to air dry. The dried smears were then stained with Spermac ${ }^{\circledR}$ stains, following the manufacturer's recommendations. A drop of immersion oil was poured onto the dried stained slide and covered with a cover slip before evaluation using the CASA microscope with a 60x objective. The percentages of acrosome-reacted, absent tails, coiled or bent tails, and total abnormalities were determined by counting 200 spermatozoa per each stained slide.

Spermatozoa viability was assessed by nigrosin-eosin stain. Six microlitres of the semen sample and $20 \mu \mathrm{L}$ of eosin stain were poured on the end of a warmed glass slide and mixed with a pipette tip on a warm 
stage at $37^{\circ} \mathrm{C}$. A drop of $20 \mu \mathrm{L}$ nigrosin stain was then poured onto the mixture on the slide and mixed with the same pipette tip. The edge of the second slide, also pre-warmed at $37^{\circ} \mathrm{C}$, was used to smear across the slide. Immediately after smearing, the smeared slide was placed on a hot Buehler® slide warmer (Buehler Ltd., 41 Waukegan road, Lake Bluff, Illinois, USA) at $120^{\circ} \mathrm{C}$ to allow fast drying. A drop of immersion oil was poured on the dried stained slide and covered with a cover slip before evaluation with CASA at 60x magnification. The percentages of viable/live (white sperm heads) and non-viable/dead (pink sperm heads), were determined by counting a total of 200 spermatozoa per each stained slide.

The study was conducted in four replicates and data were analysed statistically with the general linear model (GLM) procedures of Minitab program (Minitab 2013), using $3 \times 4$ factorial in a completely randomized design. Analysis of variance (ANOVA) was used for analysis of the results. Means of treatments were compared using Tukey's post hoc test. Significance was set at $P<0.05$.

\section{Results and Discussions}

Despite the effect of the high storage temperature of $24^{\circ} \mathrm{C}$, the results indicated that bull semen could be extended in modified Ham's F10 and TCM-199 culture media, and the commercial extender Triladyl, and stay viable for more than 24 hours. For the first time, bull semen was extended in Ham's F10 and TCM-199 culture media and survived for three days. Sperm motility and viability gradually decreased over time for various reasons such as nutrient depletion in the extenders. Triladyl, however, showed consistently better results in TM, VCL, VAP and WOB for 72 hours at controlled room temperature $24^{\circ} \mathrm{C}$ (Table 1). Afroz et al. (2008) also found consistency in buck spermatozoa motility extended in Triladyl at $5{ }^{\circ} \mathrm{C}$.

Table 1 Motility rates of extended semen with Triladyl, Ham's F10 and TCM-199 evaluated at 0, 24, 48 and 72 hours at controlled room temperature $24^{\circ} \mathrm{C}$

\begin{tabular}{|c|c|c|c|c|c|c|c|c|c|c|}
\hline Treatment & $\begin{array}{l}\text { ST } \\
(\mathrm{h}) \\
\end{array}$ & $\begin{array}{l}\text { TM } \\
(\%)\end{array}$ & $\begin{array}{l}\mathrm{PM} \\
(\%)\end{array}$ & $\begin{array}{l}\text { RAP } \\
(\%)\end{array}$ & $\begin{array}{c}\mathrm{VCL} \\
(\mu \mathrm{m} / \mathrm{s}) \\
\end{array}$ & $\begin{array}{c}\mathrm{VSL} \\
(\mu \mathrm{m} / \mathrm{s}) \\
\end{array}$ & $\begin{array}{c}\text { VAP } \\
(\mu \mathrm{m} / \mathrm{s}) \\
\end{array}$ & LIN (\%) & $\begin{array}{l}\text { STR } \\
(\%)\end{array}$ & $\begin{array}{l}\text { WOB } \\
(\%)\end{array}$ \\
\hline \multirow[t]{4}{*}{ Triladyl } & 0 & $98.8^{\mathrm{a}}$ & $27.5^{\mathrm{d}}$ & $48.8^{\mathrm{a}}$ & $146.3^{\mathrm{a}}$ & $56.8^{\mathrm{a}}$ & $83.5^{\mathrm{a}}$ & $46.0^{\mathrm{abc}}$ & $70.3^{\mathrm{ab}}$ & $61.5^{\mathrm{ab}}$ \\
\hline & 24 & $98.3^{\mathrm{a}}$ & $23.5^{\mathrm{e}}$ & $50.3^{a}$ & $146.8^{\mathrm{a}}$ & $46.5^{\mathrm{abc}}$ & $76.8^{\mathrm{a}}$ & $31.8^{\mathrm{bc}}$ & $60.3^{b c}$ & $52.5^{\mathrm{b}}$ \\
\hline & 48 & $96.5^{\mathrm{a}}$ & $22.3^{\text {ef }}$ & $47.8^{\mathrm{a}}$ & $140.0^{\mathrm{a}}$ & $43.0^{\mathrm{abc}}$ & $75.0^{\mathrm{ab}}$ & $30.3^{b c}$ & $56.3^{c}$ & $53.8^{\mathrm{b}}$ \\
\hline & 72 & $91.5^{\mathrm{a}}$ & $20.3^{f}$ & $39.3^{\mathrm{cd}}$ & $119.5^{\mathrm{ab}}$ & $34.5^{\mathrm{bcd}}$ & $62.0^{\mathrm{abc}}$ & $28.5^{\mathrm{c}}$ & $55.3^{c}$ & $52.0^{\mathrm{b}}$ \\
\hline \multirow[t]{4}{*}{ Ham's F10 } & 0 & $98.3^{\mathrm{a}}$ & $49.3^{\mathrm{a}}$ & $42.0^{\mathrm{bc}}$ & $105.8^{\mathrm{bc}}$ & $60.0^{\mathrm{a}}$ & $81.0^{\mathrm{a}}$ & $57.0^{\mathrm{a}}$ & $74.3^{\mathrm{a}}$ & $76.5^{\mathrm{a}}$ \\
\hline & 24 & $90.8^{\mathrm{b}}$ & $43.0^{\mathrm{b}}$ & $48.3^{\mathrm{a}}$ & $120.5^{\mathrm{ab}}$ & $56.3^{\mathrm{ab}}$ & $77.0^{\mathrm{a}}$ & $46.3^{\mathrm{abc}}$ & $72.8^{\mathrm{ab}}$ & $64.0^{\mathrm{ab}}$ \\
\hline & 48 & $86.3^{c}$ & $30.8^{\mathrm{c}}$ & $35.5^{\mathrm{e}}$ & $116.0^{\mathrm{ab}}$ & $49.8^{\mathrm{abc}}$ & $70.0^{\mathrm{ab}}$ & $42.8^{\mathrm{abc}}$ & $71.0^{\mathrm{ab}}$ & $60.5^{\text {cdef }}$ \\
\hline & 72 & $72.0^{d}$ & $28.0^{\mathrm{d}}$ & $27.5^{f}$ & $78.8^{\mathrm{cd}}$ & $33^{c d}$ & $45.0^{\mathrm{cd}}$ & $41.0^{\mathrm{abc}}$ & $72.3^{\mathrm{ab}}$ & $56.3^{b}$ \\
\hline \multirow[t]{4}{*}{ TCM-199 } & 0 & $98.3^{\mathrm{a}}$ & $48.5^{\mathrm{a}}$ & $36.5^{\mathrm{de}}$ & $102.0^{\mathrm{bc}}$ & $59.3^{\mathrm{a}}$ & $77.5^{\mathrm{a}}$ & $58.8^{\mathrm{ab}}$ & $76.3^{\mathrm{a}}$ & $76.3^{\mathrm{a}}$ \\
\hline & 24 & $82.5^{\mathrm{c}}$ & $40.8^{\mathrm{b}}$ & $44.3^{b}$ & $106.8^{\mathrm{bc}}$ & $52.5^{\mathrm{abc}}$ & $70.0^{\mathrm{ab}}$ & $49.0^{\mathrm{abc}}$ & $74.8^{\mathrm{a}}$ & $66.0^{\mathrm{ab}}$ \\
\hline & 48 & $71.0^{\mathrm{d}}$ & $28.8^{\mathrm{cd}}$ & $20^{9}$ & $79.5^{\mathrm{c}}$ & $39.8^{\mathrm{abc}}$ & $51.8^{\mathrm{bc}}$ & $50.8^{\mathrm{abcd}}$ & $77.8^{\mathrm{a}}$ & $65.0^{\mathrm{ab}}$ \\
\hline & 72 & $55.0^{\mathrm{e}}$ & $8.8^{9}$ & $4.3^{\mathrm{h}}$ & $47.8^{d}$ & $17.0^{\mathrm{d}}$ & $24.3^{d}$ & $34.0^{\mathrm{bc}}$ & $68.0^{\mathrm{abc}}$ & $49.8^{b}$ \\
\hline SEM & & 0.9 & 0.5 & 0.7 & 6.4 & 4.4 & 5.0 & 4.3 & 2.8 & 3.5 \\
\hline \multicolumn{11}{|l|}{$\begin{array}{l}\text { Ext. } \\
\text { Means }\end{array}$} \\
\hline Triladyl & & $96.3^{\mathrm{a}}$ & $23.4^{\mathrm{C}}$ & $46.5^{\mathrm{a}}$ & $138.1^{\mathrm{a}}$ & $45.2^{\mathrm{a}}$ & $74.3^{\mathrm{a}}$ & $34.1^{\mathrm{b}}$ & $60.5^{\mathrm{b}}$ & $54.9^{b}$ \\
\hline Ham's F10 & & $86.8^{\mathrm{b}}$ & $37.8^{\mathrm{a}}$ & $38.3^{\mathrm{b}}$ & $105.3^{b}$ & $49.8^{\mathrm{a}}$ & $68.3^{\mathrm{a}}$ & $46.8^{\mathrm{a}}$ & $72.6^{a}$ & $64.3^{\mathrm{a}}$ \\
\hline TCM-199 & & $76.7^{\mathrm{c}}$ & $31.7^{\mathrm{b}}$ & $26.5^{\mathrm{c}}$ & $84.0^{c}$ & $42.1^{\mathrm{a}}$ & $55.9^{\mathrm{b}}$ & $48.0^{\mathrm{a}}$ & $74.2^{\mathrm{a}}$ & $64.3^{\mathrm{a}}$ \\
\hline SEM & & 0.4 & 0.2 & 0.3 & 3.1 & 2.2 & 2.5 & 2.1 & 1.4 & 1.8 \\
\hline
\end{tabular}

$\overline{a, b, c, d, e, f}$ Mean values with different superscript letters in the same column differ significantly; SEM: standard error mean; ST: storage time; TM: total motility, PM: progressive motility, RAP: rapid motility, VCL: curvilinear velocity, VSL: straight line velocity, VAP: average path velocity, LIN: linearity, STR: straightness, WOB: wobble $(P<0.05)$

Triladyl had a higher spermatozoa TM rate $(96.3 \%)$ for 72 hours $(P<0.01)$ compared with modified Ham's F10 $(86.8 \%)$ and TCM-199 $(76.7 \%)$ culture media. Ham's F10 had a higher PM rate $(37.8 \%)$ than the other extenders, namely TCM-199 (31.7\%) and Triladyl (23.4\%). The earliest attempt to culture mammalian 
cell was in the 1940s, when the culture media contained only human plasma or serum. In the 1990s the welldefined albumin media additive was introduced.

Today, albumin is universally added in culture media such as Ham's F10 and TCM-199 for in vitro fertilization (IVF), and as a cryoprotectant for semen cryopreservation, as it is known to be beneficial (Cabrita et al., 2001; Blake et al., 2002). Albumin makes up 60 per cent of the total protein in the blood plasma. The culture media Ham's F10 and TCM-199 that were used in this study were both supplemented with 10\% BSA to serve as a protein supplement. The extender, storage time, and the interaction between extender and storage time, however, affected spermatozoa motility and velocity throughout the storage time in both Ham's F10 and TCM-199, compared with Triladyl. The reduction in sperm motility characteristics could be due to what previous studies have reported on oxidative stress (Nichi et al., 2007; Sarı̈zkan et al., 2009). Reactive oxygen species (ROS) produced by damaged spermatozoa phospholipids, which are toxic to normal spermatozoa, could be mitigated by the use of antioxidants at appropriate optimal concentrations.

Just as motility is considered the most important characteristic associated with the fertilizing ability of spermatozoa and as an expression of their viability and structural integrity (Kathiravan et al., 2011), spermatozoa morphological assessment is considered the most significant method of differentiating between semen of high and low fertilizing capacity (Ball \& Poters, 2004). In the current study, percentages of spermatozoa with abnormal morphology between the two Nguni bulls were not significantly different and were within the physiological range (Table 2). The morphological abnormality that was observed most in both bulls was the acrosome reacted sperm heads, which appear red in colour (Figure 1B), followed by absent tails (top arrow in Figure 1C). Other abnormalities were bent tails (second arrow in Figure 1C) and coiled tails (Figure $1 \mathrm{D}$ ). Figure $1 \mathrm{~A}$ shows normal sperm cells with intact acrosomes. No statistically significant difference in total sperm morphological abnormalities, bent tail and coiled tail was observed between the two bulls $(P>0.05)$, but there was a significant difference in absent tails and acrosome reacted $(P<0.05)$. A detailed evaluation in both bulls, however, revealed that spermatozoa with reacted acrosomes made up the greatest portion of all the abnormal sperms, followed by spermatozoa with absent tails. The least observed abnormalities (less than $2 \%$ ) were coiled and bent tails. Generally, after 72 hours' storage, the morphological quality of the two Nguni bull ejaculates under study was still high.

Table 2 Abnormal morphology rates of extended semen in Ham's F10 after 72 hours of storage at controlled room temperature of $24^{\circ} \mathrm{C}$

\begin{tabular}{lccccc}
\hline Treatment & Acrosome reacted (\%) & Absent tails (\%) & Coiled tails (\%) & Bent tails (\%) & Total abnormality (\%) \\
\hline Bull 01 & $15.0^{\mathrm{a}}$ & $7.0^{\mathrm{a}}$ & $1.0^{\mathrm{a}}$ & $2.0^{\mathrm{a}}$ & $25.8^{\mathrm{a}}$ \\
Bull 02 & $17.3^{\mathrm{b}}$ & $7.8^{\mathrm{b}}$ & $0.8^{\mathrm{a}}$ & $1.5^{\mathrm{a}}$ & $27.3^{\mathrm{a}}$ \\
SEM & 0.4 & 0.2 & 0.2 & 0.4 & 0.8
\end{tabular}

${ }^{\text {ab }}$ Mean values with different superscript letters in the same column differ significantly; SEM: standard error mean; $(P$ $<0.05)$.

Past studies have indicated that spermatozoa motility depends greatly on the available energy source in an extender or seminal plasma in the form of adenosine triphosphate (ATP), which is produced from metabolism, and therefore requires a constant supply for cell function and survival (Wattimena et al., 2009; Miki, 2007). The live and dead mean values of extended bull semen samples after 72 hours of storage are presented in Table 3. Normal live sperm cell heads appear white in colour, while the dead sperm cell heads appear pinkish (Figure 2A and B) When using nigrosin-eosin stain for viability evaluation, non-stained sperm cells were considered alive, while partially and totally stained cells were considered dead, owing to the alteration of their plasma membrane which then allowed the stain to penetrate (Felipe-Pérez et al., 2008).

Exposing fresh ejaculated semen to room temperature conditions would likely exhaust the nutrients of the seminal plasma, as they would likely have been depleted by the spermatozoa. This depletion would eventually lead to ATP deficits (Wattimena et al., 2009; Miki, 2007). Overall, this condition would disturb the efficiency in sperm motility and affects its viability. The highest percentage of TM (91.5\%) and viability (41\%) was obtained with spermatozoa samples extended with Triladyl (with egg yolk) and the lowest (55\%) TM and (25.0\%) viability was obtained with TCM-199 (with BSA). No significant difference was found between Ham's F10 (26.5\%) and TCM-199 (25.0\%). This indicated that Triladyl extender was able to supply the spermatozoa with more nutrients as the energy source than the two culture media Ham's F10 and TCM-199 
despite the fact that they were supplemented with $0.025 \mathrm{~g} / 4 \mathrm{~mL}$ maltose monohydrate and BSA $10 \%$ to serve as energy and protein source for the spermatozoa for $72 \mathrm{~h}$, respectively.

Table 3 Bull spermatozoa viability (life/dead) percentages after $72 \mathrm{~h}$ of storage at $25{ }^{\circ} \mathrm{C}$ controlled room temperature.

\begin{tabular}{lcc}
\hline Treatment & Live cells (\%) & Dead cells (\%) \\
\hline Triladyl & $41.3^{\mathrm{a}}$ & $58.7^{\mathrm{a}}$ \\
Ham's F 10 & $26.5^{\mathrm{b}}$ & $73.5^{\mathrm{b}}$ \\
TCM-199 & $25.0^{\mathrm{b}}$ & $75.0^{\mathrm{b}}$ \\
SEM & 2.6 & 2.6
\end{tabular}

${ }^{\text {ab }}$ Mean values with different superscript letters in the same column differ significantly; SEM: standard error mean; $(P$ $<0.05)$

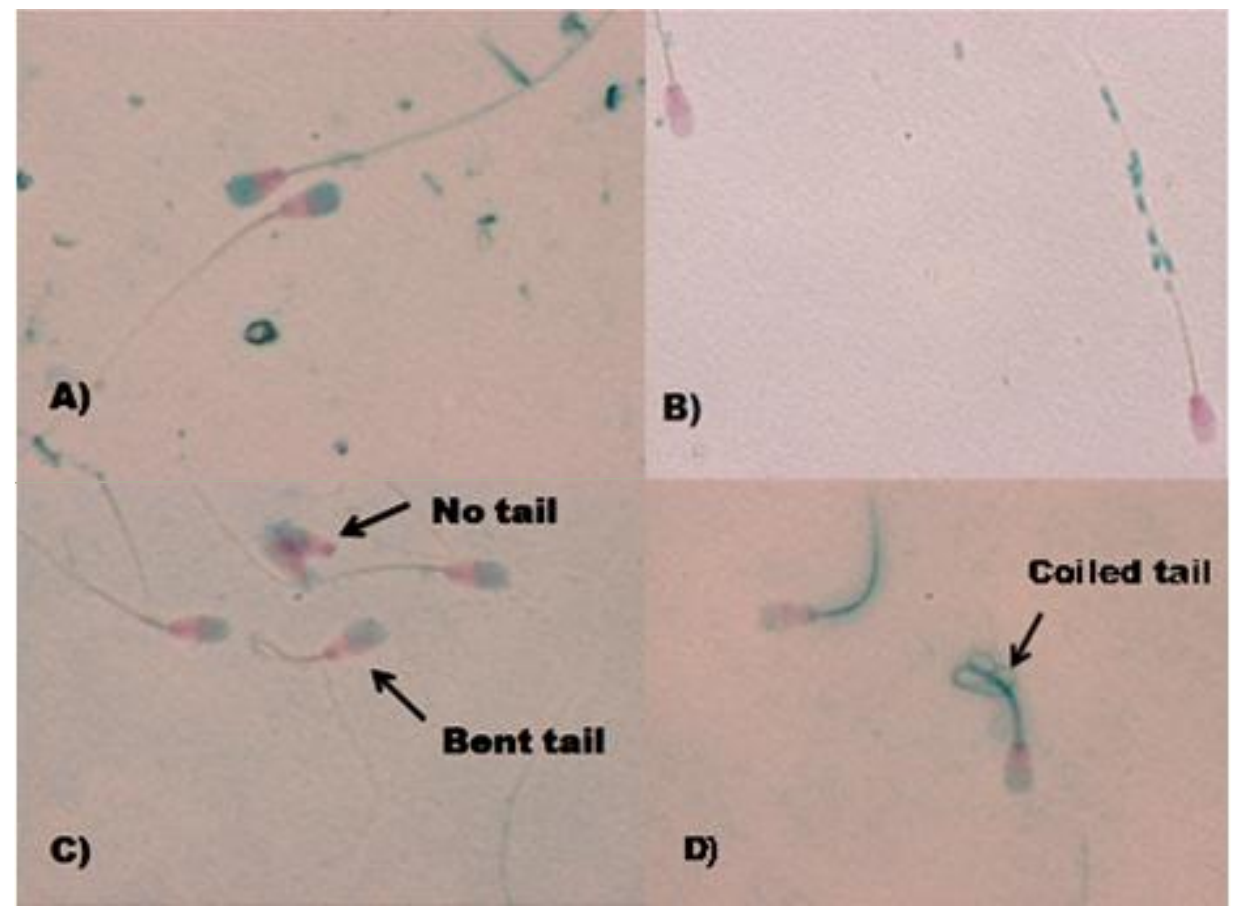

Figure 1 Images indicating bull spermatozoa morphology determined using Spermac® staining method. (A) normal cells with intact acrosome; (B) abnormal cell with reacted acrosome; (C) abnormal cells: top arrow indicates absent tail and the arrow below indicates bent tail; and (D) abnormal cell: the arrow indicates coiled tail 


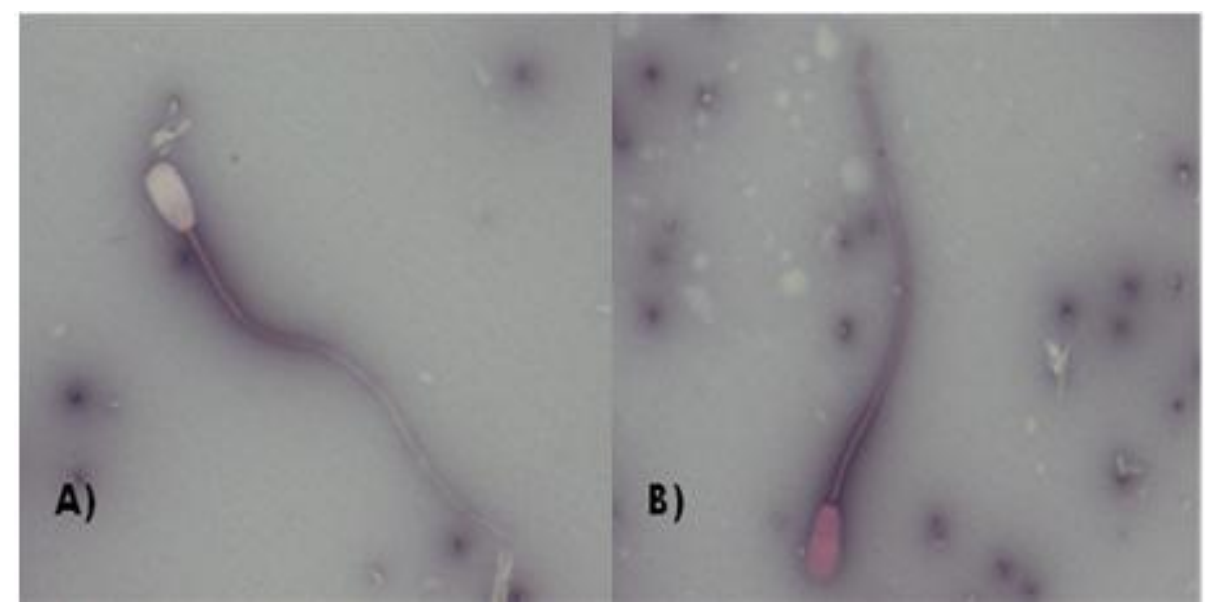

Figure 2 Images indicating bull spermatozoa viability determined using Nigrosin-eosin staining method. (A) live cell: head stained white; and (B) dead cell: head stained pink.

\section{Conclusions}

Bull semen can be preserved with the commercial extender Triladyl or modified Ham's F10 and TCM199 culture media, stored at $24{ }^{\circ} \mathrm{C}$ controlled room temperature and stay viable for 72 hours. Triladyl proved the best extender, showing higher sperm viability and total motility rates for 72 hours. Ham's F10 proved to be the second best extender, showing higher progressive motility for three days. Further research is necessary to evaluate fertility rates with Triladyl, Ham's F10 and TCM-199 as semen extenders stored at 24 ${ }^{\circ} \mathrm{C}$. Again, more work needs to be done on the use of antioxidants at appropriate optimal concentrations to mitigate the effects of ROS in extended bull semen.

\section{Acknowledgements}

The present study received financial support from National Research Foundation (NRF). The authors acknowledge the Centre of Excellence in Animal Assisted Reproduction (CEAAR) for providing the necessary facilities and Dr. K. Benyi for his suggestions and advice on statistical analysis.

\section{Authors' Contribution}

AMR carried out the experimental trials, data collection and analysis, and drafted the manuscript. OAA, LDN and LRM assisted with data collection and analysis. TLN and DMB designed the study and revised the manuscript. All authors read and approved the final manuscript.

\section{Conflict of Interest Declaration} manuscript.

The authors report no conflict of interest. The authors alone are responsible for the content and writing of the

\section{References}

Afroz, S., Islam, R., Khandoker, M.A.M.Y. \& Akter, Q.S., 2008. Cryopreservation of Black Bengal buck semen: effects of diluents and freezing on sperm motility and morphology. Anim. Sci. J. 79, 550-553.

Aires, V.A., Hinsch K.D., Schloesser, F.M., Bognera, K. \& Schloesser S.M., 2003. In vitro and in vivo comparison of egg yolk-based and soybean lecithin-based extenders for cryopreservation of bovine semen. Theriogenology 60, 269-279.

Ball, P.J.H. \& Poters, A.R., 2004. Reproduction in cattle. 3rd ed. Blackwell. ISBN 9781-4051-1545-2.

Blake, D., Svalander, P., Jin, M., Silversand, C. \& Hamberger, L., 2002. Protein supplementation of human IVF culture media. J. Assit. Reprod. Genet. 19, 137-143.

Bucak, M.N., Tuncer, P.B., Sarıözkan, S., Baspınar, N., Taspınar, M., Coyan, K., Bilgili, A., Akalın, P.P., Buyukleblebici, S., Aydos, S., Ilgaz, S., Sunguroglu, A. \& Oztuna, D., 2010. Effects of antioxidants on postthawed bovine sperm and oxidative stress parameters: Antioxidants protect DNA integrity against cryodamage. Cryobiology 61, 248-253.

Bucher, A., Kasimanickam, R., Hall, J.B., Dejarnette, J.M., Whittier, W.D., Kähn, W. \& Xu, Z., 2009. Fixed-time Al pregnancy rate following insemination with frozen-thawed or fresh-extended semen in progesterone supplemented CO-Synch protocol in beef cows. Theriogenology 71, 1180-1185.

Cabrita, E., Anel, L. \& Herraez, M.P., 2001. Effect of external cryoprotectants as membrane stabilizers on cryopreserved rainbow trout sperm. Theriogenology 56, 623-635. 
Crespilho, A.M., Nichi, M., Guasti, P.N., Freitas-Dell'Aqua, C.P., Sá Filho, M.F., Maziero, R.R., Dell'Aqua Jr, J.A. \& Papa, F.O., 2014. Sperm fertility and viability following $48 \mathrm{~h}$ of refrigeration: Evaluation of different extenders for the preservation of bull semen in liquid state. Anim. Reprod. Sci. 146, 126-133.

Felipe-Pérez, Y.E., Juárez-Mosqueda, M.L., Hernández-González, E.O. \& Valencia, J.J., 2008. Viability of fresh and frozen bull sperm compared by two staining techniques. Acta. Vet. Brasilica. 2, 123-130.

Gil, J., Lundhein, N., Soderquist, L. \& Martines-Rodriguez, H., 2003. Influence of extender, temperature, and addition glycerol on post-thaw spermatozoa parameters in ram semen. Theriogenology 59, 1241-1255.

Kathiravan, P., Kalatharan, J., Karthikeya, G., Rengarajan, K. \& Kadirvel, G., 2011. Objective sperm motion analysis to assess dairy bull fertility using computer-aided system: a review. Reprod. Dom. Anim. 46, 165-172.

Kasimanickam, R., Kasimanickam, V., Tibracy, A. \& Pelzer, K., 2011. Effect of semen extenders on spermatozoa parameters of ram semen during liquid storage at $4{ }^{\circ} \mathrm{C}$. Small Rum. Res. 99, 208-213.

Lebbie, S.H.B. \& Kagwini, E., 1996. Small ruminant research and development in Africa.

Proceedings of the Third Biennial Conference of the African Small Ruminant Research Network, UICC, Kampala, Uganda, 5-9 December 1994. ILRI (International Livestock Research Institute) Nairobi, Kenya. pp. 326.

Mafukata, M.A., 2014. Predicting the factors affecting farm productivity amongst communal cattle farmers in Vhembe District, Limpopo Province. Inter. J. Agric. Sci. 4, 12.

Mafukata, M.A., 2015. Factors having the most significance on the choice and selection of marketing channels amongst communal cattle farmers in Vhembe District, Limpopo Province. J. Hum. Ecol. 19, 77-87.

Miki, K., 2007. Energy metabolism and sperm function. Soci. Reprod. Fertil. Suppl. 65, 309-325.

Nichi, M., Goovaerts, I.G.F., Cortada, C.N.M., Barnabe, V.H., DeClercq, J.B.P. \& Bolas, P.E.J., 2007. Roles of lipid peroxidation and cytoplasmic droplets in vitro fertilization capacity of sperm collected from bovine epididymides stored at 4 to $34^{\circ} \mathrm{C}$. Theriogenology $67 ; 334-340$.

Sarı̈̈zkan, S., Bucak, M.N., Tuncer, P.B., Büyükleblebici, S. \& Cantürk, F., 2014. Influence of various antioxidants added to TCM-199 on post-thaw bovine sperm parameters, DNA integrity and fertilizing ability. Cryobiology 68,129-133.

Sarı̈zkan, S., Bucak, M.N., Tuncer, P.B., Ulutas, P.A. \& Bilgen, A., 2009. The influence of cysteine and taurine on microscopic oxidative stress parameters and fertilizing ability of bull semen following cryopreservation. Cryobiology 58, 134-138.

Shannon, P. \& Curson, B., 1984. Effect of storage temperature on the viability and fertility of bovine sperm diluted and stored in Caprogen. N. Z. J. Agric. Res. 27, 173-7.

Singh, A.K., Singh, V.K., Narwade, B.M., Mohanty, T.K. \& Atreja, S.K., 2012. Comparative quality assessment of buffalo (bubalusbubalis) semen chilled $\left(5^{\circ} \mathrm{C}\right)$ in egg yolk- and soya milk-based extenders. Rep. Dom. Anim., 47, 590600.

Sirard, M.A., Parrish, J.J., Ware, C.B., Leibfried-Rutledge, M.L. \& First, N.L., 1988. The culture of bovine oocytes to obtain developmentally competent embryos. Biol. Reprod. 39, 546-552.

Stroebel, A., Swanepoel, F.J.C. \& Pell, A.N., 2011. Sustainable smallholder livestock systems - a case study of Limpopo Province, South Africa. J. livest. Sci. 139, 186-190.

Vishwanath, R. \& Shannon, P., 2000. Storage of bovine semen in liquid and frozen state. Anim. Reprod. Sci. 62, $23-53$.

Verberckmoes, S., Van Soom, A., Dewulf, J., De Pauw, I. \& de Kruif, A., 2004. Storage of fresh bovine in a diluent based on the ionic composition of cauda epididymal plasma. Reprod. Domest. Anim. 39, 410-6.

Verberckmoes, S., Van Soom, A., Dewulf, J. \& Kruif, A., 2005. Comparison of three diluents for the storage of fresh bovine semen. Theriogenology 63, 912-922.

Wattimena, J., Parera dan, F. \& Veerman, M., 2009. Effect of maltose concentration in Tris dilution on epididymal spermatozoa quality of Bali bull preserved at $5^{\circ} \mathrm{C}$. J. Indonesian. Trop. Anim. Agric. pp. 34.

Yoshida, M., 2000. Conservation of sperms: Current status and new trends. Anim. Reprod. Sci. 60, 349-355. 